\title{
Characteristics of an Iron-Reducing, Moderately Acidophilic Actinobacterium Isolated from Pyritic Mine Waste, and Its Potential Role in Mitigating Mineral Dissolution in Mineral Tailings Deposits
}

\author{
Ivan Nancucheo ${ }^{1, * \mathbb{D}}$ and D. Barrie Johnson ${ }^{2}$ \\ 1 Facultad de Ingeniería y Tecnología, Universidad San Sebastián, Lientur 1457, Concepción 4080871, Chile \\ 2 School of Natural Sciences, Bangor University, Deiniol Road, Bangor LL57 4UF, UK; \\ d.b.johnson@bangor.ac.uk \\ * Correspondence: inancucheo@gmail.com; Tel.: +56-(41)-2487433
}

Received: 11 June 2020; Accepted: 28 June 2020; Published: 2 July 2020

check for updates

\begin{abstract}
Reactive pyritic mine tailings can be populated by chemolithotrophic prokaryotes that enhance the solubilities of many metals, though iron-reducing heterotrophic microorganisms can inhibit the environmental risk posed by tailings by promoting processes that are the reverse of those carried out by pyrite-oxidising autotrophic bacteria. A strain (IT2) of Curtobacterium ammoniigenes, a bacterium not previously identified as being associated with acidic mine wastes, was isolated from pyritic mine tailings and partially characterized. Strain IT2 was able to reduce ferric iron under anaerobic conditions, but was not found to catalyse the oxidation of ferrous iron or elemental (zero-valent) sulfur, and was an obligate heterotrophic. It metabolized monosaccharides and required small amounts of yeast extract for growth. Isolate IT2 is a mesophilic bacterium, with a temperature growth optimum of $30^{\circ} \mathrm{C}$ and is moderately acidophilic, growing optimally at $\mathrm{pH} 4.0$ and between pH 2.7 and 5.0. The isolate tolerated elevated concentrations of many transition metals, and was able to grow in the cell-free spent medium of the acidophilic autotroph Acidithiobacillus ferrooxidans, supporting the hypothesis that it can proliferate in acidic mine tailings. Its potential role in mitigating the production of acidic, metal-rich drainage waters from mine wastes is discussed.
\end{abstract}

Keywords: acidophile; Curtobacterium ammoniigenes; heterotroph; mine tailings; iron reduction

\section{Introduction}

Waste materials from metal mining, such as mineral tailings, have little or no economic value, making their exploitation not profitable. In the context of mine management, tailings have the potential to pose a long-term threat to the environment. Mine tailings are one of the major waste products generated during the mining of metal ores, and have variable physical and chemical compositions, dependent on the ore body being processed and the mining operations [1]. Following the crushing and grinding of ores (comminution), target minerals are segregated from other (gangue) minerals by froth flotation. The fine-grain mineral wastes produced (tailings) may account for up to $99 \%$ of the primary ore body [2]. While the mineralogical composition of tailings is highly variable, they frequently contain significant amounts of potentially acid-generating minerals, such as pyrite $\left(\mathrm{FeS}_{2}\right)$, though the acidity generated in fresh tailings can be neutralized by basic materials, such as lime $(\mathrm{CaO})$, that are often added to enhance froth flotation [3].

The dissolution of sulfide minerals requires water and an oxidizing agent, which may be either molecular oxygen or ferric iron, and may occur in either aerobic or anaerobic (micro) environments via mechanisms that have been widely reported [4]. In many cases, the potential for acid generation 
greatly exceeds the neutralization potential of tailings, and liquors within and draining from tailing deposits can become highly acidic, and enriched with soluble transition metals derived from the dissolution of residual sulfidic (e.g., chalcopyrite; $\mathrm{CuFeS}_{2}$ ) and other minerals. In addition, such waters are highly toxic to most life-forms [5]. The reactivity of pyritic mine tailings derives from their small particle size, and their content of acid-generating and metal-rich sulfidic minerals [6]. There have been a number of studies on the microbiology of tailing deposits located in different parts of the world [7-10]. Indigenous prokaryotes include well-known chemolitho-autotrophic acidophiles, such as Acidithiobacillus and Leptospirillum spp., and chemolitho-heterotrophic species (e.g., Ferrimicrobium and Ferroplasma spp.), which use the ferrous iron and/or reduced sulfur as electron donors. Most species of iron-oxidizing acidophiles that oxidize iron when oxygen is present can also use ferric iron as an alternative electron acceptor in anaerobic environments [11]. Some species of obligately heterotrophic acidophiles, including Acidiphilium, Acidocella and Acidobacterium which are able to reduce ferric iron but not oxidize ferrous iron, have also been identified in mine tailings [8]. Interestingly, heterotrophic acidophilic bacteria that reduce iron attach to sulfide minerals and form biofilms. Pyrite particles colonized with Acidiphilium and Acidocella spp. were found to be less susceptible to accelerated oxidation by mineral-oxidizing acidophiles, and a technique based on this observation, referred to as "bioshrouding", was suggested as a method of partially securing reactive mine wastes [12].

In a series of mesocosm experiments, set up to examine how engineering the microbial communities of reactive mine tailings could be used to limit the generation of acidity and the release of metals [13], it was found that those that had either not been inoculated, or had been inoculated only with a mixed culture of iron-oxidizing chemolithotrophic acidophiles, became heavily colonized $\left(\sim 3 \times 10^{6}\right.$ colony forming units/g), within 12 months, by a bacterium that was identified (from its partial 16S rRNA gene sequence) as a strain of Curtobacterium ammoniigenes ( $99 \%$ gene similarity). This bacterium (and two others that were also isolated from the tailings) was inferred to have originated from the tailings themselves, and had not been completely eradicated by pre-treatment of the tailings, which were washed with strong $(3 \mathrm{M})$ sulfuric acid to remove the residual lime. C. ammoniigenes is a heterotrophic, ammonium-oxidizing actinobacterium, the type strain of that had been isolated from water weeds growing in highly acidic ( $\mathrm{pH} 2-4)$ swamps adjacent to acid sulfate soils in Vietnam [14]. There have been no previous reports of this bacterium in acidic mine-impacted environments, such as acid mine drainage, biomining sites, or waste rock and tailings deposits. Curtobacterium ammoniigenes strain IT2 has been shown to be a moderate-acidophile and an obligate heterotroph, which tolerates elevated concentrations of many transition metals, and also catalyses the dissimilatory reduction of ferric iron. These characteristics infer that is has a potential role in mitigating the formation and migration of acidic, metal-rich waters from tailings dumps.

\section{Materials and Methods}

\subsection{Isolation and Cultivation of C. ammoniigenes IT2}

The bacterium was originally isolated from pyritic tailing obtained from the Agua Blanca nickel-copper mine, Spain [13]. Briefly, homogenized tailing samples were serially diluted onto solid medium that contained $5 \mathrm{mM}$ fructose/ $0.02 \%(w / v)$ yeast extract, acidophile basal salts (ABS) and trace elements (TE) [15], adjusted to $\mathrm{pH} 3.5$ with sulfuric acid, and incubated aerobically for 14 days at $30^{\circ} \mathrm{C}$. The isolate was purified by repeated single-colony using the same medium and incubation conditions. After the purity of the isolate was confirmed, DNA was extracted and 16S rRNA genes were amplified, sequenced and compared to those in public databases, as described previously [16]. Single colony was transferred into liquid medium containing $5 \mathrm{mM} /$ fructose $/ 0.005 \%(w / v)$ yeast extract, and ABS adjusted to $\mathrm{pH} 3.5$, incubated at $30^{\circ} \mathrm{C}$ and shaken at $100 \mathrm{rpm}$. 


\section{2. $p H$ and Temperature Characteristics}

C. ammoniigenes IT2 was grown in batch mode in a bioreactor $(1 \mathrm{~L}$ liquid volume in a $2 \mathrm{~L}$ reactor vessel; Electrolab Ltd., Tewkesbury, UK) under conditions of fixed temperature and $\mathrm{pH}$. The liquid medium used contained $5 \mathrm{mM}$ fructose/0.005\% (w/v) yeast extract, and ABS/TE and cultures were aerated at $1 \mathrm{~L} / \mathrm{min}$ and stirred at $150 \mathrm{rpm}$. To determine the effect of $\mathrm{pH}$ on its growth, cultures were maintained at $30^{\circ} \mathrm{C}$ and varying $\mathrm{pH}$ (2.7-5.0; controlled by automated addition of $0.1 \mathrm{M} \mathrm{NaOH}$ ), and to determine the effect of temperature, cultures were maintained at between 22 and $37^{\circ} \mathrm{C}$ with $\mathrm{pH}$ maintained at 4.0. Samples were withdrawn from the reactor at regular intervals, the optical densities at $600 \mathrm{~nm}$ were measured $\left(\mathrm{OD}_{600}\right)$, and culture doubling times were evaluated from semi-logarithmic plots of changes in $\mathrm{OD}_{600}$ against time.

\subsection{Organic Nutrition of C. ammoniigenes IT2}

The ability of the isolate IT2 to grow in the absence of yeast extract was tested by comparing growth in $5 \mathrm{mM}$ fructose/ABS/TE liquid medium with and without yeast extract. The isolate was also tested for growth in liquid medium ( $\mathrm{pH} 4.0$, containing $0.005 \%$ yeast extract and ABS/TE) amended with various organic compounds, including sugars, alcohols, aliphatic acids and amino acids (listed in Table 1). Different concentrations of substrates were used to approximately equalize their carbon-equivalents (i.e., $5 \mathrm{mM}$ for $\mathrm{C}_{6}$ substrates, $10 \mathrm{mM}$ for $\mathrm{C}_{3}$ substrates, etc.). Replicate universal bottles were incubated $30{ }^{\circ} \mathrm{C}$ and $\mathrm{OD}_{600}$ were measured over 7 days.

\subsection{Oxidation of Iron and Reduced Sulfur}

C. ammoniigenes IT2 was assessed for its ability to grow autotrophically in oxic medium, using ferrous iron or elemental sulfur as electron donors in organic carbon-free medium, containing $5 \mathrm{mM}$ ferrous sulfate $(\mathrm{pH} 3.0)$ or $1 \%(w / v)$ elemental sulfur $(\mathrm{pH} 3.5)$. Non-inoculated controls were also prepared. The ability to oxidize ferrous iron and sulfur when grown heterotrophically was also tested in the same medium, amended with $0.002 \%(w / v)$ yeast extract. Oxidation of ferrous iron was determined by measuring changes in concentrations of ferrous iron using the ferrozine assay [17], and changes in culture $\mathrm{pH}$ as a measure of sulfur oxidation, again relative to non-inoculated controls.

\subsection{Growth of C. ammoniigenes IT2 in Spent Medium of Acidithiobacillus ferrooxidans}

Acidithiobacillus (A.) ferrooxidans (ATCC $23270^{\mathrm{T}}$ ) was grown in batch mode in a bioreactor using $5 \%$ $(w / v)$ elemental sulfur as electron donor and $\mathrm{ABS} / \mathrm{TE}$, at $\mathrm{pH} 1.8$ and $30^{\circ} \mathrm{C}$. The bioreactor was stirred at $150 \mathrm{rpm}$ and aerated at $1 \mathrm{~L} / \mathrm{min}$. After 25 days of growth, the culture was removed and cell-free culture liquors was obtained by centrifugation $(10,000 \times g ; 15 \mathrm{~min})$ followed by filtration through $0.2 \mu \mathrm{m}$ (pore size) cellulose nitrate membrane filters (Whatman, UK). Cell-free culture liquors were adjusted to $\mathrm{pH} 3.5$ with $1 \mathrm{M} \mathrm{NaOH}$, filtered, and $30 \mathrm{~mL}$ aliquots were dispensed into $100 \mathrm{~mL}$ conical flasks. These were then inoculated, in duplicate, with C. ammoniigenes IT2, and a third (non-inoculated) duplicate set used as sterile controls. Cultures were incubated and shaken at $150 \mathrm{rpm}$, at $30{ }^{\circ} \mathrm{C}$ for up 12 days, and samples were withdrawn at days $0,4,8$ and 12 to enumerate bacterial cells (using a Thoma counting chamber and Leitz phase contrast microscope). Concentrations of glycolic acid were determined by a colorimetric technique [18], and total dissolved organic carbon (DOC) was measured using a LABTOC DOC analyzer (Pollution and Process Monitoring, UK).

\subsection{Tolerance of C. ammoniigenes IT2 to Some Transition Metals}

To evaluate its tolerance to four transition metals frequently often found in elevated concentrations in pyritic tailings, C. ammoniigenes IT2 was grown in liquid medium containing $5 \mathrm{mM}$ fructose, $0.005 \%$ $(w / v)$ yeast extract, ABS and TE, supplemented with sterile solutions of copper, ferrous, nickel and zinc sulfates (concentrations used listed in Table 2). Culture $\mathrm{pH}$ was adjusted to $\mathrm{pH} 4.0$ with sulfuric acid, and $\mathrm{pH} 2.7$ in the case of ferrous iron (to minimize chemical oxidation and precipitation of iron), and the 
cultures were incubated at $30^{\circ} \mathrm{C}$ for 7 days. Positive growth was assessed from $\mathrm{OD}_{600}$ measurements. In the case of ferrous iron, where culture turbidity was also due to some abiotic formation of ferric iron, growth was assessed by measuring changes in fructose concentrations using ion chromatography [19], and concentrations of ferrous iron were also measured after 7 days to determine the amount of this metal remaining in the solution.

Table 1. Comparison of organic substrates utilized by isolate IT2, and Acidobacterium capsulatum and Acidiphilium cryptum also found in mine tailings. ++, strong growth; +, weak growth; -, no growth. Key: (++) $\mathrm{OD}_{600}$ values $>0.6 ;(+) \mathrm{OD}_{600}$ values between 0.1 and $0.6 ;(-) \mathrm{OD}_{600}<0.1$.

\begin{tabular}{|c|c|c|c|}
\hline Substrate & IT2 & Acidobacterium capsulatum $^{a}$ & Acidiphilium cryptum ${ }^{a}$ \\
\hline Glucose & ++ & ++ & ++ \\
\hline Galactose & ++ & ++ & ++ \\
\hline Fructose & ++ & $\mathrm{Nd}$ & $\mathrm{Nd}$ \\
\hline Xylose & ++ & ++ & ++ \\
\hline Mannose & ++ & ++ & + \\
\hline Arabinose & - & ++ & ++ \\
\hline Rhamnose & - & $\mathrm{Nd}$ & $\mathrm{Nd}$ \\
\hline Maltose & + & ++ & + \\
\hline Lactose & + & ++ & + \\
\hline Glycerol & ++ & - & ++ \\
\hline Mannitol & + & - & ++ \\
\hline Sorbitol & - & $\mathrm{Nd}$ & $\mathrm{Nd}$ \\
\hline Acetic acid & - & $\mathrm{Nd}$ & $\mathrm{Nd}$ \\
\hline Citric acid & - & $\mathrm{Nd}$ & $\mathrm{Nd}$ \\
\hline Glutamic acid & - & $\mathrm{Nd}$ & $\mathrm{Nd}$ \\
\hline Asparagine & - & $\mathrm{Nd}$ & $\mathrm{Nd}$ \\
\hline Arginine & - & $\mathrm{Nd}$ & $\mathrm{Nd}$ \\
\hline Lysine & - & $\mathrm{Nd}$ & $\mathrm{Nd}$ \\
\hline Leucine & - & $\mathrm{Nd}$ & $\mathrm{Nd}$ \\
\hline Proline & - & $\mathrm{Nd}$ & $\mathrm{Nd}$ \\
\hline Ethanol & - & - & - \\
\hline Methanol & - & $\mathrm{Nd}$ & $\mathrm{Nd}$ \\
\hline Tryptone soy broth & ++ & $\mathrm{Nd}$ & $\mathrm{Nd}$ \\
\hline Yeast extract & ++ & $\mathrm{Nd}$ & $\mathrm{Nd}$ \\
\hline
\end{tabular}

Table 2. Minimum inhibitory concentration (MIC) of some metals (mM) recorded for C. ammoniigenes strain IT2, with the highest concentration at which growth of the bacterium was observed indicated in parentheses.

\begin{tabular}{cc}
\hline Metal & MIC (mM) \\
\hline $\mathrm{Cu}^{2+}$ & $15(10)$ \\
$\mathrm{Fe}^{2+}$ & $250^{\mathrm{a}}(200)$ \\
$\mathrm{Zn}^{2+}$ & $125(100)$ \\
$\mathrm{Ni}^{2+}$ & $100(75)$
\end{tabular}

a The largest concentration tested to avoid precipitation of iron.

\section{Results and Discussion}

Pale yellow colonies of strain IT2 were observed, after 7 days of incubation, on yeast extract/fructose solid medium $\mathrm{pH}$ 3.5. Cells were non-motile rods of irregular shape, and did not appear to produce endospores. The isolate did not oxidize elemental sulfur or ferrous iron autotrophically or heterotrophically. It grew poorly on defined single carbon sources, but the addition of small amounts of yeast extract promoted growth on sugars, fructose in particular, presumably due to the requirement of one or more growth factors (Table 1). The isolate was able to use a relatively limited range of defined organic substrates, including glucose, fructose and galactose, compared with Acidobacterium 
capsulatum and Acidiphilium cryptum also found in mine tailings. Its substrate range differed from other acidophilic bacteria found in mine tailings [20]. All of the amino acids tested inhibited the growth of the bacterium at the concentrations tested (i.e., growth was less than in the presence of yeast extract alone), even though they grew well on tryptone soya broth. It was also noted that some of the low molecular weight organic acids tested, such as acetic and citric acid, inhibited the growth of strain IT2 [21]. The absence of growth in an organic carbon-free medium suggested that $C$. ammoniigenes IT2 is an obligate heterotroph.

Culture doubling times of isolate IT2 grown at different temperatures and $\mathrm{pH}$ values are shown in Figure 1. Strain IT2 grew between $\mathrm{pH} 2.7$ and 5.0, with a $\mathrm{pH}$ growth optimum of 4.0. The optimum temperature for growth was found to be at $30^{\circ} \mathrm{C}$, and the maximum temperature at which growth was observed at $37^{\circ} \mathrm{C}$. Under optimum conditions of temperature and $\mathrm{pH}$, its culture doubling time was $3.8 \mathrm{~h}$, equivalent to a growth rate of $0.18 \mathrm{~h}^{-1}$. The isolate was unable to grow below $\mathrm{pH} 2.7$ and above $\mathrm{pH}$ 5.0, indicating that it is a moderate acidophile. Strain IT2 is therefore more tolerant of extreme acidity than $\mathrm{C}$. ammoniigenes $\mathrm{B}^{2} 5^{\mathrm{T}}$ ( $\mathrm{pH}$ range 3.5-8.0, with optimal growth at $\mathrm{pH} 4.0$ ). All other species of Curtobacterium are neutrophiles [14].
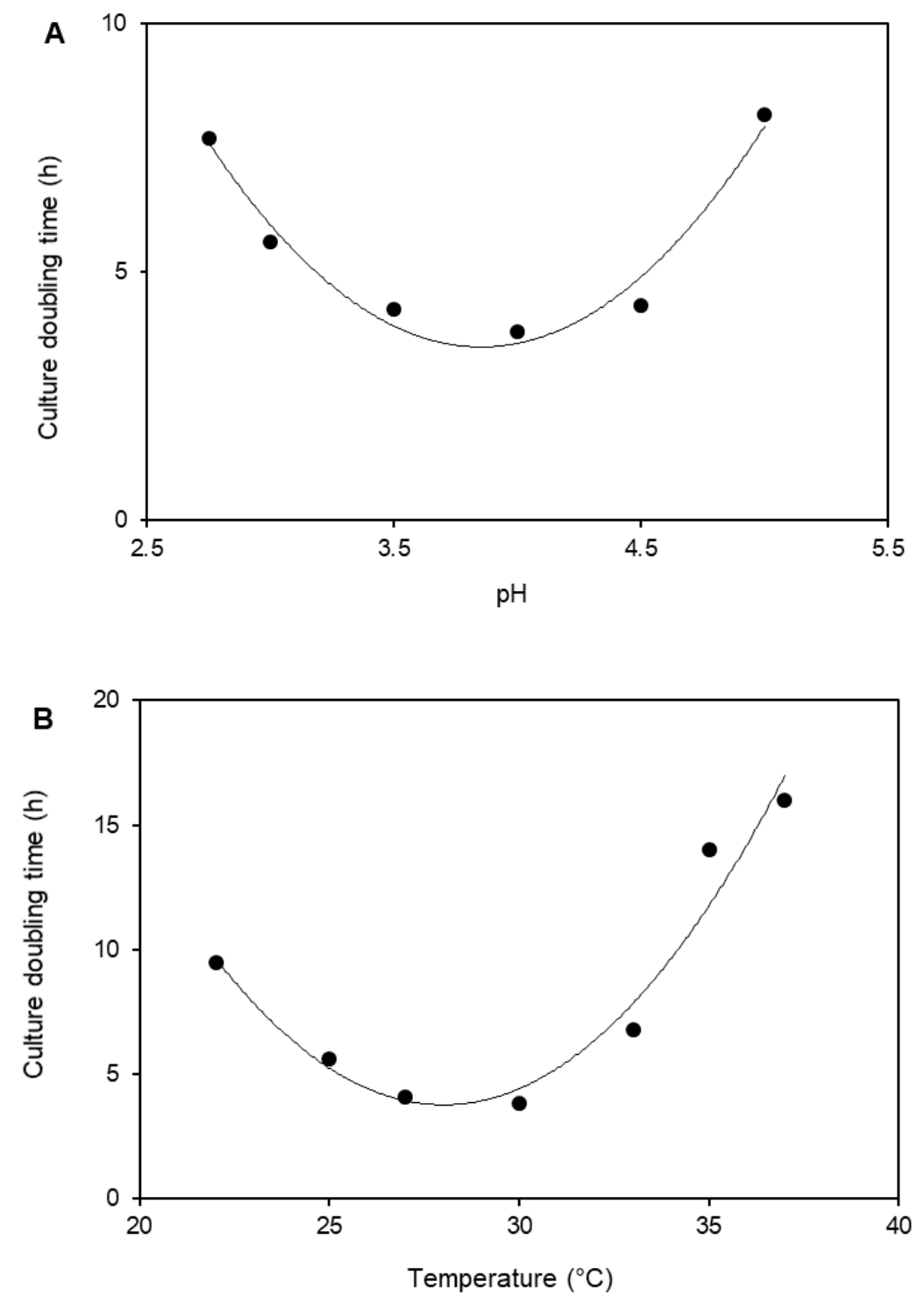

Figure 1. Effect of $(\mathrm{A}) \mathrm{pH}\left(\right.$ at $30{ }^{\circ} \mathrm{C}$ ) and (B) temperature (at constant $\mathrm{pH}$ of 4.0 ) on the growth of isolate IT2. 
In addition, Curtobacterium isolate IT2 showed similar copper tolerance to that reported for Acidiphilum cryptum [22], a heterotrophic acidophilic bacteria that has also been found in pyritic mine tailings [8] and can also grow on a wide range of monosaccharides, dicarboxylic acids and tricarboxylic acids. As is the case with many other acidophilic bacteria, isolate IT2 exhibited a high tolerance to elevated concentrations of ferrous iron, zinc and nickel (Table 2), which helps to explain why it is able to proliferate in pyritic tailings [13]. Tolerance to transition metals is another major characteristic of heterotrophic bacteria isolated from mineral tailings, though, in general, heterotrophs are less tolerant to dissolved metals than iron-oxidizing chemolithotrophs (A. ferrooxidans in particular) [23].

C. ammoniigenes IT2 was able to grow in the spent medium of $A$. ferrooxidans. Figure 2 shows that numbers of $C$. ammoniigenes cells increased by over one order of magnitude within 12 days, and that this was accompanied by a decrease in the concentration of total DOC. However, only about $24 \%$ of the total DOC was metabolized over this period, and the cessation of growth of C. ammoniigenes isolate suggests that the residual DOC was not metabolized by this strain. No changes in the concentration of DOC were observed in the control cultures containing sterile spent medium of $A$. ferrooxidans, which were also confirmed to be devoid of bacterial cells (data not shown). This result provides further support that primary-producing chemolitho-autotrophic acidophilic bacteria, such as A.ferrooxidans, can support the growth of heterotrophic bacteria by providing them with electron donors and carbon sources. Diaby et al. [8] proposed a model using the microbiological and geochemical results to explain how autotrophic acidophiles sustained the growth of heterotrophic iron-reducers present in mine tailings at the Andina mine, CODELCO, Chile. DOC, mainly lysates and exudates from A. ferrooxidans and other primary producers, was proposed to sustain the heterotroph communities dominated by Acidiphilium, Acidocella and Acidobacterium spp. Carbon transfer between acidophilic prokaryotes that either fix or produce $\mathrm{CO}_{2}$ was demonstrated by Kermer et al. [24], using protein-based stable isotope probing, to be a two-way process. The syntrophic relationship of the acidophilic species involves organic carbon, derived from autotroph (as exudates or cell lysates), being used as the carbon source by heterotrophic bacteria, and $\mathrm{CO}_{2}$ generated by heterotrophic species being using as carbon source by autotrophs. The latter is particularly important in low $\mathrm{pH}$ environments, where the solubility of $\mathrm{CO}_{2}$ is very low [25]. Previously, Schnaitman and Lundgren [26] had shown that 10\% of labelled carbon $\left({ }^{14} \mathrm{CO}_{2}\right)$ was leaked by $A$. ferrooxidans into its growth medium, and pyruvic acid was identified as one the low molecular weight exudates. Besides, low molecular weight carboxylic acids, such as formate, acetate and pyruvate, were detected from two copper mine tailings [27].

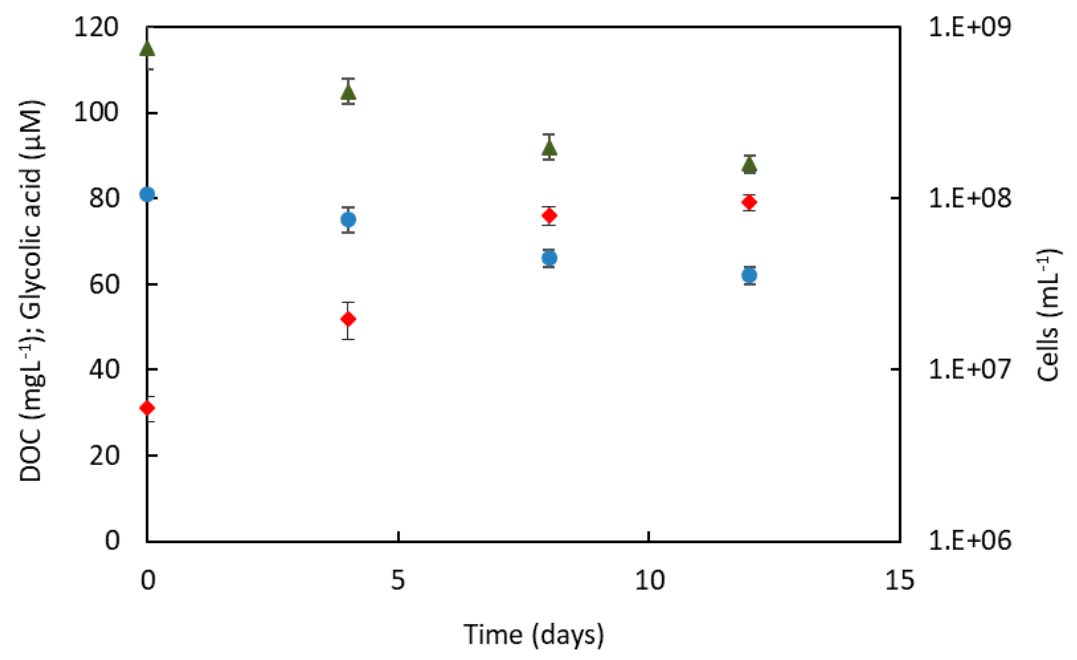

Figure 2. Growth of C. ammoniigenes IT2 on spent A. ferrooxidans medium. ( $\downarrow)$ number of cells; $(\bullet)$ dissolved organic carbon; $(\mathbf{\Lambda})$; glycolic acid. The symbols indicate means for duplicate cultures, and error bars indicate range. 
Nancucheo and Johnson [28] reported that glycolic acid was produced and excreted by mineral-oxidizing bacteria, such as L. ferriphilum, Acidithiobacillus caldus and A. ferrooxidans, and demonstrated that this was used as a carbon and energy source by Sulfobacillus spp. The results of this study confirmed that glycolic acid in the spent medium of $A$. ferrooxidans, as previously reported by Nancucheo and Johnson [28], was also used, at least in part ( 20\%), by the Curtobacterium isolate (Figure 2).

To mitigate the risk of reactive mineral tailings generating metal-rich, extremely acidic waste drainage waters, they are usually stored under water to limit contact with oxygen. Even so, ferric iron, generated in the aerobic upper layers, can diffuse into tailings and oxidize sulfide minerals in the absence of oxygen [29]. Diaby et al. [8] found that, in pyritic tailings (deposits below the "oxidation front", the junction between the oxidation and neutralization zones), the dissimilatory reduction of ferric iron was a dominant geochemical process, since ferric iron, produced by iron-oxidizing acidophiles in the aerobic tailings surface and migrating downwards in percolating drainage waters, can act as a terminal electron acceptor, for both heterotrophic and many autotrophic species (including A. ferrooxidans), when oxygen is limited or absent. Extremely acidic environments usually contain ferrous and ferric iron in much greater concentrations than those typically found in neutral $\mathrm{pH}$ water bodies [30]. The redox potential of the ferrous/ferric couple is relatively high, at $\mathrm{pH}$ values less than $\sim 2.0$ ( +680 mV in sulfate-rich liquors; [31]), due to the enhanced solubility of both ionic species of this metal. This makes ferric iron a thermodynamically attractive alternative electron acceptor to oxygen in acidic environments, both for heterotrophic (coupled to organic carbon) and autotrophic (coupled to reduced sulfur or hydrogen) acidophiles [25]. Previously, Nancucheo and Johnson [13] showed that the $C$. ammoniigenes strain IT2 catalysed the dissimilatory reductive dissolution of amorphous ferric hydroxide (concurrent with a corresponding increase in cell numbers), when incubated under anaerobic conditions in cultures containing glucose as the electron donor. This important trait was not previously described for this genus, and adds another species of mesophilic, acidophilic bacteria to the list of those that can use the dissimilatory reduction of ferric iron to support growth in oxygen-limited cultures in highly acidic environments, such as those found in many pyritic mine tailings. Most currently known iron-reducing heterotrophic acidophiles found in pyritic mine tailings are Proteobacteria [32]. Interestingly, dissimilatory reduction of ferric iron has also been described for other genera of acidophilic actinobacteria, including Ferrimicrobium acidiphilum, Ferrithrix thermotolerans, Aciditerrimonas ferrireducens and Acidithrix ferrooxidans [33], and the novel recently-described genus Acidiferrimicrobium australe [11]. In addition, species of acidophilic actinobacteria, except Aciditerrimonas ferrireducens and the isolate IT2, also oxidize ferrous iron.

By lowering concentrations of ferric iron, the prime oxidant of sulfide minerals in low $\mathrm{pH}$ environments, C. ammoniigenes strain IT2 (and other iron-reducing acidophiles) can, in theory, help control the production of metal-rich mine waters, especially where mineral wastes are ecologically engineered to stimulate such bacteria by limiting oxygen ingress and (possibly) promoting the influx of organic electron donors (e.g., algal exudates, [13]). New strategies are required to stabilize the storage of mineral tailings, which represents a long-term engineering and environmental challenge, where, occasionally, catastrophic environmental pollution has occurred due to the failings of the retaining dam of a tailings impoundment [6]. Preventing the oxidation of metallic sulfides in mineral tailings has been highlighted as a key criterion for the ecological restoration of mine tailings by revegetation, and heterotrophic bacteria such as Curtobacterium spp. may possibly be used as biological indicators for monitoring mineral tailings during the process of restoration, in order to minimize the solubilization of a variety of transition metals associated with sulfide minerals.

\section{Conclusions}

This study provides further evidence to explain how C. ammoniigenes, a moderately acidophilic, heterotrophic actinobacterium, can be found and can proliferate in mine pyritic tailings, where primary producers, such as chemolithotrophic acidophiles like A.ferrooxidans, sustain the growth of heterotrophic 
iron-reducing bacteria, which may contribute to mitigating the formation of acidic, metal-rich waters from mineral tailing dumps.

Author Contributions: I.N. and D.B.J. conceptualized the work and co-wrote the manuscript. I.N. carried out the laboratory experiments. All authors have read and agreed to the published version of the manuscript.

Funding: I.N. is grateful to the Mecesup Programme of the Chilean Government.

Conflicts of Interest: The authors declare no conflict of interest.

\section{References}

1. Nancucheo, I.; Bitencourt, J.; Sahoo, P.K.; Alves, J.; Siqueira, J.O.; Oliveira, G. Recent developments for remediating acidic mine waters using sulfidogenic bacteria. BioMed Res. Int. 2017, 2017, 1-17. [CrossRef] [PubMed]

2. Dold, B. Basic concepts in environmental geochemistry of sulfidic mine-waste management. In Waste Management; InTech: Rijeka, Croatia, 2010; pp. 173-198.

3. Zanin, M.; Lambert, H.; Du Plessis, C. Lime use and functionality in sulphide mineral flotation: A review. Miner. Eng. 2019, 143, 105922. [CrossRef]

4. Vera, M.; Schippers, A.; Sand, W. Progress in bioleaching: Fundamentals and mechanisms of bacterial metal sulfide oxidation - part A. Appl. Microbiol. Biotechnol. 2013, 97, 7529-7541. [CrossRef] [PubMed]

5. González, D.; Liu, Y.; Villa-Gómez, D.K.; Southam, G.; Hedrich, S.; Galleguillos, P.; Colipai, C.; Nancucheo, I. Performance of a sulfidogenic bioreactor inoculated with indigenous acidic communities for treating an extremely acidic mine water. Miner. Eng. 2019, 131, 370-375. [CrossRef]

6. Falagán, C.; Grail, B.M.; Johnson, D.B. New approaches for extracting and recovering metals from mine tailings. Miner. Eng. 2017, 106, 71-78. [CrossRef]

7. Schippers, A.; Breuker, A.; Blazejak, A.; Bosecker, K.; Kock, D.; Wright, T. The biogeochemistry and microbiology of sulfidic mine waste and bioleaching dumps and heaps, and novel Fe(II)-oxidizing bacteria. Hydrometallurgy 2010, 104, 342-350. [CrossRef]

8. Diaby, N.; Dold, B.; Pfeifer, H.-R.; Holliger, C.; Johnson, D.B.; Hallberg, K.B. Microbial communities in a porphyry copper tailings impoundment and their impact on the geochemical dynamics of the mine waste. Environ. Microbiol. 2007, 9, 298-307. [CrossRef]

9. Bryan, C.; Hallberg, K.B.; Johnson, D.B. Mobilisation of metals in mineral tailings at the abandoned São Domingos copper mine (Portugal) by indigenous acidophilic bacteria. Hydrometallurgy 2006, 83, 184-194. [CrossRef]

10. Wakelin, S.A.; Anand, R.R.; Reith, F.; Gregg, A.L.; Noble, R.R.P.; Goldfarb, K.C.; Andersen, G.L.; Desantis, T.Z.; Piceno, Y.M.; Brodie, E.L. Bacterial communities associated with a mineral weathering profile at a sulfidic mine tailings dump in arid Western Australia. FEMS Microbiol. Ecol. 2012, 79(2), 298-311. [CrossRef]

11. González, D.; Huber, K.J.; Tindall, B.; Hedrich, S.; Rojas-Villalobos, C.; Quatrini, R.; Dinamarca, M.A.; Ibacache-Quiroga, C.; Schwarz, A.; Canales, C.; et al. Acidiferrimicrobium australe gen. nov., sp. nov., an acidophilic and obligately heterotrophic, member of the Actinobacteria that catalyses dissimilatory oxido-reduction of iron isolated from metal-rich acidic water in Chile. Int. J. Syst. Evol. Microbiol. 2020, 70, 3348-3354. [CrossRef]

12. Johnson, D.B. Recent developments in microbiological approaches for securing mine wastes and for recovering metals from mine waters. Miner. 2014, 4, 279-292. [CrossRef]

13. Nancucheo, I.; Johnson, D.B. Significance of microbial communities and interactions in safeguarding reactive mine tailings by ecological engineering. Appl. Environ. Microbiol. 2011, 77, 8201-8208. [CrossRef] [PubMed]

14. Aizawa, T.; Ve, N.B.; Kimoto, K.-I.; Iwabuchi, N.; Sumida, H.; Hasegawa, I.; Sasaki, S.; Tamura, T.; Kudo, T.; Suzuki, K.-I.; et al. Curtobacterium ammoniigenes sp. nov., an ammonia-producing bacterium isolated from plants inhabiting acidic swamps in actual acid sulfate soil areas of Vietnam. Int. J. Syst. Evol. Microbiol. 2007, 57, 1447-1452. [CrossRef]

15. Nancucheo, I.; Rowe, O.F.; Hedrich, S.; Johnson, D.B. Solid and liquid media for isolating and cultivating acidophilic and acid-tolerant sulfate-reducing bacteria. FEMS Microbiol. Lett. 2016, 363. [CrossRef] [PubMed] 
16. Rowe, O.F.; Sánchez-España, J.; Hallberg, K.B.; Johnson, D.B. Microbial communities and geochemical dynamics in an extremely acidic, metal-rich stream at an abandoned sulfide mine (Huelva, Spain) underpinned by two functional primary production systems. Environ. Microbiol. 2007, 9, 1761-1771. [CrossRef] [PubMed]

17. Stookey, L. Ferrozine-a new spectrophotometric reagent for iron. Anal. Chem. EE.UU 1970, 42, 779-781.

18. Calkins, V. Microdetermination of glycolic and oxalic acids. Ind. Eng. Chem. Anal. Ed. 1943, 15, 762-763. [CrossRef]

19. Nancucheo, I.; Johnson, D.B. Selective removal of transition metals from acidic mine waters by novel consortia of acidophilic sulfidogenic bacteria. Microb. Biotechnol. 2011, 5, 34-44. [CrossRef]

20. Kosako, Y.; Tano, T.; Kishimoto, N. Acidobacterium capsulatum gen. nov., sp. nov.: An acidophilic chemoorganotrophic bacterium containing menaquinone from acidic mineral environment. Curr. Microbiol. 1991, 22, 1-7. [CrossRef]

21. Urschel, M.R.; Hamilton, T.L.; Roden, E.E.; Boyd, E.S. Substrate preference, uptake kinetics and bioenergetics in a facultatively autotrophic, thermoacidophilic crenarchaeote. FEMS Microbiol. Ecol. 2016, 92. [CrossRef]

22. Mahapatra, N.R.; Banerjee, P. Extreme tolerance to cadmium and high resistance to copper, nickel and zinc in different Acidiphilium strains. Lett. Appl. Microbiol. 1996, 23, 393-397. [CrossRef]

23. Johnson, D.B.; Hallberg, K.B. Carbon, iron and sulfur metabolism in acidophilic micro-organisms. Adv. Microb. Physiol. 2008, 54, 201-255. [CrossRef]

24. Kermer, R.; Hedrich, S.; Taubert, M.; Baumann, S.; Schlömann, M.; Johnson, D.B.; von Bergen, M.; Seifert, J. Elucidation of carbon transfer in a mixed culture of Acidiphilium cryptum and Acidithiobacillus ferrooxidans using protein-based stable isotope probing. J. Integr. OMICS. 2012, 2, 37-45.

25. Johnson, D.B. Microbial communities and interactions in low $\mathrm{pH}$ environments. In Acidophiles: Life in Extremely Acidic Environments; Caister Academic Press: Wymondham, UK, 2016; pp. 121-137.

26. Schnaitman, C.; Lundgren, D.G. Organic compounds in the spent medium of Ferrobacillus ferrooxidans. Can. J. Microbiol. 1965, 11, 23-27. [CrossRef] [PubMed]

27. Dold, B.; Blowes, D.W.; Dickhout, R.; Spangenberg, J.E.; Pfeifer, H.-R. Low molecular weight carboxylic acids in oxidizing porphyry copper tailings. Environ. Sci. Technol. 2005, 39, 2515-2521. [CrossRef]

28. Nancucheo, I.; Johnson, D.B. Production of glycolic acid by chemolithotrophic iron- and sulfur-oxidizing bacteria and its role in delineating and sustaining acidophilic sulfide mineral-oxidizing consortia. Appl. Environ. Microbiol. 2009, 76, 461-467. [CrossRef]

29. Dold, B. Evolution of acid mine drainage formation in sulphidic mine tailings. Minerals 2014, 4, $621-641$. [CrossRef]

30. Johnson, D.B.; Kanao, T.; Hedrich, S. Redox transformations of iron at extremely low pH: Fundamental and applied aspects. Front. Microbiol. 2012, 3, 3-96. [CrossRef]

31. Johnson, D.B.; Hedrich, S.; Pakostova, E. Indirect redox transformations of iron, copper, and chromium catalyzed by extremely acidophilic bacteria. Front. Microbiol. 2017, 8, 135. [CrossRef]

32. Quatrini, R.; Johnson, D.B. Acidophiles: Life in Extremely Acidic; Caister Academic Press: Haverhill, UK, 2016; pp. 265-284.

33. Jones, R.; Johnson, D.B. Acidithrix ferrooxidans gen. nov., sp. nov.; a filamentous and obligately heterotrophic, acidophilic member of the Actinobacteria that catalyzes dissimilatory oxido-reduction of iron. Res. Microbiol. 2015, 166, 111-120. [CrossRef]

(C) 2020 by the authors. Licensee MDPI, Basel, Switzerland. This article is an open access article distributed under the terms and conditions of the Creative Commons Attribution (CC BY) license (http://creativecommons.org/licenses/by/4.0/). 